\title{
Adaptasi Family Caregivers dalam Merawat Pasien di Rumah Selama Masa Pandemi COVID-19
}

\author{
Sri Rahayu", Iis Sapitri ${ }^{2}$ \\ ${ }^{1,2}$ Fakultas Ilmu Kesehatan, Institut Kesehatan dan Teknologi PKP DKI Jakarta \\ e-mail: srirahayu1903@gmail.com
}

\begin{abstract}
The COVID-19 pandemic has changed the way of life of many people, especially in the patients' care. This also happens to family caregivers who take care of patients at home. Caring for the patient at home is not easy and requires more attention to maintain the patients' health condition and prevent from the COVID-19. Thus, necessary to give information about the adaptation of family caregivers in caring for patients at home during the COVID-19 pandemic. Outcome Family caregivers can adapt in caring for patients at home. Activities are carried out offline and online using a Poster, PowerPoint, and Zoom Meeting applications with a total of 28 participants. Characteristics of family caregivers are the average age of $35.89 \pm 16.48$ years with a minimum age of 17 years old and a maximum age of 73 years old. Most of them are women are 18 people (64.29\%), 16 people unemployed (57.14\%), and 12 people who live in Jakarta (42.86\%). Most of the participants who answered correctly about the adaptation of family caregivers during the COVID-19 pandemic were 22 people (78.57\%). Knowledge of the participants (family caregivers), have good knowledge in caring for patients at home, but need to be followed up and monitored continuously by cadres or stakeholders from each region.
\end{abstract}

Keywords: adaptation, family caregivers, patients care

\begin{abstract}
Abstrak
Pandemi COVID-19 telah mengubah tatanan kehidupan, terlebih dalam cara perawatan pasien. Inipun juga terjadi pada family caregivers yang merawat pasien di rumah. Perawatan pasien di rumah tidaklah mudah dan perlu kehati-hatian supaya kondisi kesehatan pasien stabil dan tidak terpapar COVID-19. Sehingga perlu adanya informasi tentang adaptasi family caregivers dalam melakukan perawatan pasien di rumah selama masa pandemi COVID-19. family caregivers dapat beradaptasi dalam melakukan perawatan pasien di rumah. Kegiatan dilakukan secara offline dan online yaitu dengan menggunakan media Poster, Power Point, aplikasi Zoom Meeting dengan jumlah peserta sebanyak 28 orang. Karakteristik family caregivers adalah rata-rata berusia $35.89 \pm 16.48$ tahun dengan usia minimal 17 tahun dan usia maksimal 73 tahun. Sebagian besar perempuan yaitu sejumlah 18 orang $(64,29 \%)$, tidak bekerja sejumlah 16 orang $(57,14 \%)$, dan berdomisili di Jakarta sejumlah 12 orang $(42,86 \%)$. Sebagian besar menjawab dengan benar tentang adaptasi family caregivers selama pandemi COVID-19 adalah sejumlah 22 orang (78.57\%). Pengetahuan peserta dalam pengabdian kepada masyarakat ini yaitu family caregivers, mayoritas memiliki pengetahuan yang baik dalam merawat pasien di rumah, namun perlu ditindaklanjuti dan dilakukan pemantauan secara terus menerus oleh kader atau pemangku kepentingan dari masingmasing wilayah.
\end{abstract}

Kata Kunci: adaptasi; family caregivers; merawat pasien

\section{PENDAHULUAN}

Penyebaran Corona Virus Disease 2019 (COVID-19) masih terjadi sampai saat ini. Penyebaran virus ini dapat terjadi baik secara langsung maupun tidak langsung. Penyebaran langsung dapat terjadi ketika seseorang melakukan kontak langsung dengan orang yang terkonfirmasi COVID-19. Sedangkan penyebaran secara tidak langsung dapat terjadi melalui perantara baik objek hidup maupun mati yang terpapar virus korona. Sejumlah 
aktivitas yang dapat menimbulkan droplet diantaranya adalah batuk, bersin, berbicara, meludah, dan bernyanyi. Aktivitas perlu dihindari, terutama kelompok rentan. Orang yang rentan atau beresiko tinggi tertular COVID-19 tersebut adalah lansia, orang yang sakit kronis, orang dengan penyakit autoimun, ibu hamil, anak-anak, orang yang bepergian ke daerah pandemi, dan tenaga kesehatan (Yusriani et al., 2020; Zhou, 2020).

Berbagai upaya telah dilakukan oleh pemerintah untuk menekan penyebaran COVID-19. Upaya pencegahan yang sudah dilakukan diantaranya yaitu 3M (mencuci tangan, memakai masker, dan menjaga jarak), social distancing and physical distancing, lock down, permberlakukan PSBB (Pembatasan Sosial Berskala Besar) baik daerah maupun nasional, karantina rumah, dan isolasi diri (Kementerian Dalam Negeri, 2020; Kementerian Kesehatan RI, 2020c). Baru-baru ini juga telah dilaksanakan pemberian vaksin Coronavac pada tanggal 13 Januari 2021. Selanjutnya, pemberian vaksin ini akan dilanjutkan ke prioritas utama sampai kepada masyarakat umum.

Situasi pandemi COVID-19 juga telah mengubah tatanan kehidupan di masyarakat. Terlebih lagi bagi orang yang merawat pasien dengan penyakit kronis d rumah. Orang yang merawat pasien ini seringkali disebut sebagai caregivers atau family caregivers (Family Caregiver Alliance, 2006; National Alliance for Caregiving \& AARP, 2004). Pada masa pandemi ini tugas, peran, dan tanggungjawab mereka menjadi lebih besar. Family caregivers harus memantau kondisi pasien dan memastikan kesehatannya baik-baik saja. Jadwal kontrol pasien ke rumah sakit bisa saja mengalami perubahan, ada rasa takut ke rumah sakit, atau perasaan lainnya. Hal ini membuat family caregivers lebih berhati-hati dalam menjaga kesehatan pasien tersebut.

Mayoritas pasien yang dirawat oleh family caregivers di rumah adalah pasien yang terdiagnosis dengan penyakit hipertensi, stroke, jantung, dan diabetes (Family Caregiver Alliance, 2006; Hwang, Luttik, Dracup, \& Jaarsma, 2010; Janssen, Spruit, Wouters, \& Schols, 2012; National Alliance for Caregiving \& AARP, 2004). Pasien dengan penyakit ini termasuk kedalam kelompok yang renatan. Sehingga family caregivers perlu menerapkan protokol kesehatan yang sangat ketat. Mengingat family caregivers merupakan orang yang sangat besar kontribusinya dalam memberikan perawatan kepada pasien di rumah (Rahayu, 2017, 2019; Rahayu \& Rahmawati, 2020). Family caregivers perlu mendapatkan pemahaman yang tepat tentang cara perawatan pasien di rumah pada masa pandemi ini. Karena tentunya, cara perawatan pasien sebelum ada COVID-19 dan setelah ada COVID-19 tentu berbeda. Hasil penelitian yang dilakukan sebelumnya juga menyatakan bahwa family caregivers pasien butuh informasi tentang cara perawatan pasien (Rahayu, 2017).

Maka dari itu, perlu diadakannya sebuah kegiatan yang bertujuan untuk memberikan pemahaman kepada family caregivers tentang adaptasi kebiasaan baru dalam melakukan perawatan pasien dirumah selama masa pandemi COVID-19. Kegiatan ini diharapkan mendapat antusias dari masyarakat dan mampu meningkatkan pengetahuan family caregivers secara khusus. Permasalahan yang sudah dijelaskan diatas maka penulis mencoba untuk memecahkan masalah dengan memberikan informasi kesehatan tentang cara perawatan pasien di rumah selama pandemi COVID-19.

\section{METODE PELAKSANAAN}

Kegiatan pengabdian kepada masyarakat (PKM) ini telah dilaksanakan pada tanggal 4-8 Juli 2021 dan tanggal 14 September 2021. Kegiatan ini dilakukan secara langsung tatap muka dengan peserta, dan juga secara online melalui zoom 
meeting. Kegiatan dilaksanakan dengan menggunakan media Poster, Power Point, aplikasi Zoom Meeting. Pelaksanaan kegiatan dilakukan secara offline dan online dan di broadcast oleh beberapa asisten pelaksana pengabdian kepada masyarakat.

Kegiatan ini dimulai dengan menyusun proposal pengabdian masyarakat tentang rencana kegiatan, menyusun bahan dan materi informasi kesehatan, membuat kuesioner singkat untuk digunakan sebagai bahan evaluasi, menyebarluaskan kepada masyarakat. Target utama peserta adalah family caregivers yang merawat pasien di rumah. Mahasiswa yang dilibatkan dalam PKM ini adalah sejumlah 7 orang mahasiswa S1 Keperawatan Semester 6. Peserta yang mengikuti kegiatan PKM ini adalah sejumlah 28 orang.

\section{TARGET DAN LUARAN}

1. Target

Target kegiatan pengabdian kepada masyarakat ini adalah untuk memberikan informasi kesehatan tentang adaptasi family caregivers dalam melakukan perawatan pasien di rumah selama masa pandemi COVID19.

2. Luaran

Luaran yang dijanjikan dalam kegiatan pengabdian kepada masyarakat ini adalah terpublikasinya kegiatan ini dalam jurnal nasional terakreditasi pengabdian kepada masyarakat.

\section{HASIL DAN PEMBAHASAN \\ Karakteristik Peserta PKM}

Tabel 1. Karakteristik Peserta PKM ( $\mathrm{n}=28)$

\begin{tabular}{lcc}
\hline Karakteristik & Mean \pm SD & $\begin{array}{c}\text { Frekuensi } \\
(\%)\end{array}$ \\
\hline Usia & \\
Jenis Kelamin & $35.89 \pm 16.48$ & \\
$\quad$ Laki-laki & $10(35.71 \%)$ \\
$\quad$ Perempuan & $18(64.29 \%)$ \\
Pekerjaan & \\
$\quad$ Bekerja & $12(42.86 \%)$ \\
$\quad$ Tidak Bekerja & $16(57.14 \%)$ \\
Domisili & \\
\hline
\end{tabular}

$\begin{array}{lc}\text { Jakarta } & 12(42.86 \%) \\ \text { Bogor } & 1(3.57 \%) \\ \text { Depok } & 4(50 \%) \\ \text { Bekasi } & 5(17.86 \%) \\ \text { Cibinong } & 1(3.57 \%) \\ \text { Cianjur } & 2(7.14 \%) \\ \text { Bandung } & 1(3.57 \%) \\ \text { Kebumen } & 2(7.14 \%)\end{array}$

Pada tabel 1 menunjukkan bahwa karakteristik family caregivers dalam PKM ini adalah rata-rata berusia $35.89 \pm 16.48$ tahun dengan usia minimal 17 tahun dan usia maksimal 73 tahun. Sebagian besar perempuan yaitu sejumlah 18 orang $(64,29 \%)$, tidak bekerja sejumlah 16 orang $(57,14 \%)$, dan berdomisili di Jakarta sejumlah 12 orang $(42,86 \%)$.

Edukasi Adaptasi Family Caregivers Dalam Merawat Pasien di Rumah Selama Masa Pandemi COVID-19

Tabel 2. Edukasi Adaptasi Family Caregivers Dalam Merawat Pasien di Rumah Selama Masa Pandemi COVID-19 $(\mathbf{n}=28)$

\begin{tabular}{|c|c|c|c|}
\hline \multirow{2}{*}{ No } & \multirow{2}{*}{ Pernyataan } & \multicolumn{2}{|c|}{ Frekuensi (\%) } \\
\hline & & Benar & Salah \\
\hline 1. & $\begin{array}{l}\text { Orang yang } \\
\text { rentan } \\
\text { terinfeksi } \\
\text { COVID-19 }\end{array}$ & $\begin{array}{c}27 \\
(96.43 \%)\end{array}$ & $1(3.57 \%)$ \\
\hline 2. & $\begin{array}{l}\text { Pengertian } \\
\text { hipertensi }\end{array}$ & $28(100 \%)$ & 0 \\
\hline 3. & $\begin{array}{l}\text { Adaptasi family } \\
\text { caregivers } \\
\text { selama } \\
\text { pandemi } \\
\text { COVID-19 }\end{array}$ & $\begin{array}{c}22 \\
(78.57 \%)\end{array}$ & $6(21.43 \%)$ \\
\hline 4. & $\begin{array}{l}\text { Cara Perawatan } \\
\text { Hipertensi } \\
\text { selama } \\
\text { pandemi } \\
\text { COVID-19 }\end{array}$ & $28(100 \%)$ & 0 \\
\hline 5. & $\begin{array}{l}\text { Pentingnya } \\
\text { pengukuran } \\
\text { tekanan darah } \\
\text { secara rutin }\end{array}$ & $28(100 \%)$ & 0 \\
\hline 6. & $\begin{array}{l}\text { Jenis makanan } \\
\text { yang dibatasi } \\
\text { pada pasien } \\
\text { hipertensi }\end{array}$ & $28(100 \%)$ & 0 \\
\hline
\end{tabular}
peserta menjawab $100 \%$ benar semua pada 
pernyataan "pengertian hipertensi", "cara perawatan hipertensi selama pandemi COVID-19", "pentingnya pengukuran tekanan darah secara rutin", "dan jenis makanan yang dibatasi pada pasien hipertensi". Namun, pada pernyatan tentang "orang yang rentan terinfeksi COVID-19" adalah sejumlah 27 orang (96.43\%), dan "adaptasi family caregivers selama pandemi COVID-19" adalah sejumlah 22 orang $(78.57 \%)$.
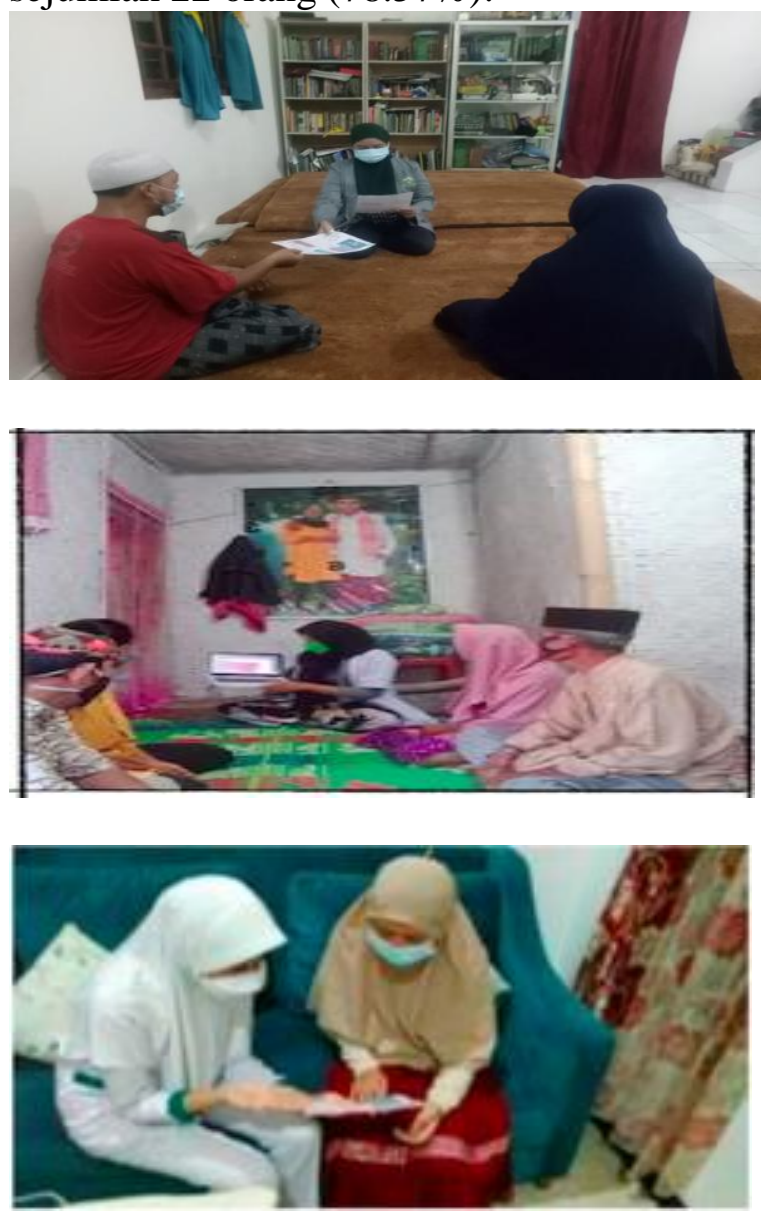

Gambar 1. Beberapa contoh kegiatan PKM offline

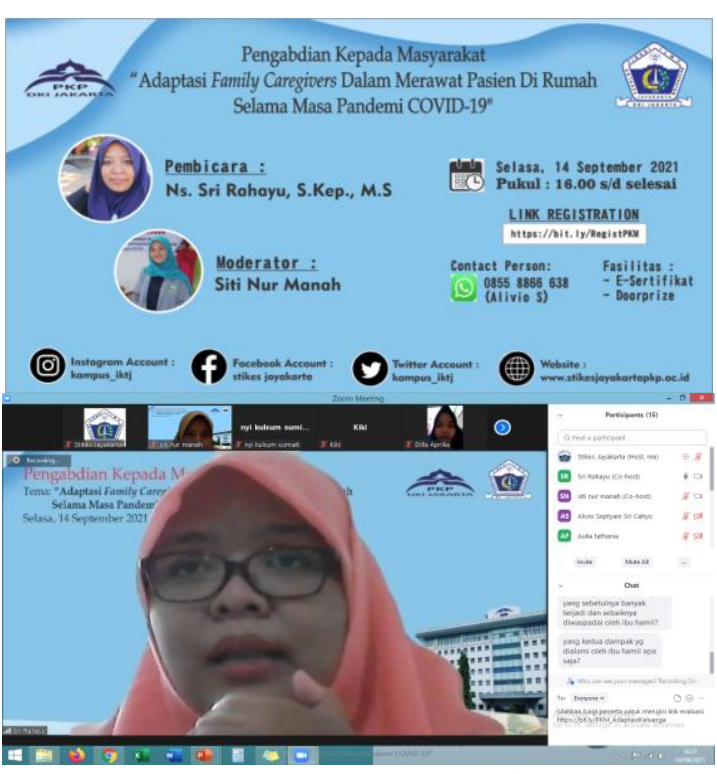

Gambar 2. PKM online

\section{PEMBAHASAN}

Kegiatan PKM ini dilaksanakan secara offline pada bulan Juli dan secara online pada tanggal 14 September 2021. Media yang digunakan yaitu Poster, Power Point, aplikasi Zoom Meeting. Pelaksana PKM kegiatan dilakukan oleh pembicara bersama-sama dengan beberapa asisten pelaksana PKM. Kegiatan PKM secara tatap muka dilakukan pada bulan Juli dengan menerapkan protokol kesehatan dan dibatasi dengan mengundang 2 orang untuk diberikan penyuluhan oleh asisten PKM. Total peserta yang terlibat pada bulan Juli 2021 adalah sejumlah 13 orang. Pada bulan Juli 2021 ini kasus COVID-19 di Indonesia mengalami lonjakan kasus dan juga angka kematian (CNN Indonesia, 2021). Sehingga kegiatan PKM dilakukan secara door to door oleh pelaksana PKM ke keluarga dengan penyakit hipertensi . Pelaksanaan PKM secara door to door juga pernah dilakukan oleh orang lain karena efektif untuk menghindari adanya kerumunan dan menekan penyebaran COVID-19 \{Formatting Citation\}. Sedangkan pada bulan September 2021 dilakukan secara online dengan mengundang keluarga dari pasien hipertensi, dan yang hadir sejumlah 15 orang. PKM online serupa juga pernah 
dilakukan oleh orang lain yaitu edukasi kepada lansia melalui streaming youtube (Melia, S., Triana, H., \& Prasetyo, 2021). Metode online lebih dipilih mengingat untuk mencegah penyebaran COVID-19, terutama pada kelompok-kelompok yang rentan terpapar cOVID-19. Kegiatan PKM ini ditujukan pada keluarga pada pasien hipertensi karena salah satu penyakit yang beresiko tinggi untuk tertularnya COVID19 adalah penyakit hipertensi. Panduan dari Kementerian Kesehatan republic Indonesia menyebutkan bahwa Penyakit Tidak Menular seperti Hipertensi sangat beresiko terinfeksi COVID-19 (Kementerian Kesehatan RI, 2020b).

Karakteristik family caregivers dalam PKM ini adalah rata-rata berusia $35.89 \pm 16.48$ tahun dengan usia minimal 17 tahun dan usia maksimal 73 tahun. Sebagian besar perempuan yaitu sejumlah 18 orang $(64,29 \%)$, tidak bekerja sejumlah 16 orang $(57,14 \%)$, dan berdomisili di Jakarta sejumlah 12 orang $(42,86 \%)$.

Hasil PKM ini didukung oleh penelitian sebelumnya yang menyebutkan bahwa mayoritas family caregivers adalah perempuan (Rahayu, 2017; Rahayu \& Rahmawati, 2019). Pada organisasi Caregivers disebutkan juga bahwa sebagian besar caregivers adalah perempuan (National Alliance for Caregiving, 2015; National Alliance for Caregiving \& AARP, 2004; Rahayu, 2017). Perempuan dinilai memiliki naluri keibuan, yang membuat dirinya peduli terhadap orang lain dan dalam hal ini adalah melakukan perawatan bagi anggota keluarga yang di cintainya. Usia rata-rata peserta adalah 35 tahun yang menunjukkan usia dewasa. Kategori usia ini disebutkan dalam kategori usia sesuai acuan dari departemen kesehatan Republik Indonesia (Depkes RI, 2009). Rentang usia peserta yaitu 17 tahun sampai dengan 73 tahun. Rentang usia ini berkaitan juga status pekerjaan family caregivers dimana pada rentang usia tersebut family caregivers tidak bekerja. Usia 17 tahun, menunjukkan bahwa peserta masih menempuh pendidikan. Sedangkan usia 73 tahun, peserta sudah tidak bekerja/ pensiun. Sehingga family caregivers dapat meluangkan waktunya untuk merawat anggota keluarganya yang sakit karena hipertensi. Untuk domilisi mayoritas adalah tinggal di Jakarta, kemudian bekasi, dan yang paling jauh adalah dari Kebumen. Hal ini karena pelaksanaan PKM dilaksanakan door to door dan online, sehingga peserta PKM bisa dari mana saja, dan dari berbagai daerah.

Pengetahuan peserta PKM mayoritas adalah baik. Peserta menjawab $100 \%$ benar semua pada pernyataan "pengertian hipertensi", "cara perawatan hipertensi selama pandemi COVID-19”, "pentingnya pengukuran tekanan darah secara rutin", "dan jenis makanan yang dibatasi pada pasien hipertensi". Namun, pada pernyatan tentang "orang yang rentan terinfeksi COVID-19" adalah sejumlah 27 orang (96.43\%), dan "adaptasi family caregivers selama pandemi COVID-19" adalah sejumlah 22 orang $(78.57 \%)$. Hal ini menunjukkan bahwa peserta memahami tentang penyakit hipertensi sampai dengan cara perawatannya. Akan tetapi, masih ada pemahaman yang kurang terkait pemahaman tentang adaptasi family caregivers selama masa pandemi COVID19. Pemahaman peserta bahwa selama pandemi COVID-19, cukup pakai masker saja. Padahal Satgas COVID-19 mewajibkan untuk menerapkan minimal $3 \mathrm{M}$ yaitu mencuci tangan, memakai masker, dan menjauhi kerumunan (Anies, 2020; Kementerian Dalam Negeri, 2020; Kementerian Kesehatan RI, 2020a; Yusriani et al., 2020).

\section{KESIMPULAN DAN SARAN}

\section{Kesimpulan}

Kesimpulan dari PKM ini adalah karakteristik family caregivers dalam PKM ini adalah rata-rata berusia $35.89 \pm 16.48$ tahun dengan usia minimal 17 tahun dan 
usia maksimal 73 tahun. Sebagian besar perempuan yaitu sejumlah 18 orang $(64,29 \%)$, tidak bekerja sejumlah 16 orang $(57,14 \%)$, dan berdomisili di Jakarta sejumlah 12 orang $(42,86 \%)$. Sebagian besar menjawab dengan benar tentang adaptasi family caregivers selama pandemi COVID-19 adalah sejumlah 22 orang (78.57\%). Pengetahuan peserta PKM mayoritas adalah baik.

\section{Saran}

Perlu ditindaklanjuti dan dilakukan pemantauan secara terus menerus oleh kader atau pemangku kepentingan dari masingmasing wilayah. Semoga laporan ini dapat dimanfaatkan dengan sebaik-baiknya bagi pembaca yang budiman.

\section{UCAPAN TERIMAKASIH}

Kami mengucapkan Terima Kasih kepada STIKes Jayakarta yang sekarang telah berubah bentuk menjadi Institut Kesehatan dan Teknologi PKP DKI Jakarta atas Hibah PKM yang diberikan dan terimakasih juga kepada para mahasiswa tercinta (Siti Nur Manah, Sisi Indah Putri, Alivio Septyani, Aulia Fathania, Irna Aprillia, Rashellia Putri, dan Zumrotus Sholikhah) atas kerjasamanya dalam menyukseskan kegiatan ini.

\section{DAFTAR PUSTAKA}

Anies. (2020). COVID-19: Seluk Beluk Corona Virus. (N. Hidayah, Ed.). Jogjakarta: Jogjakarta: ARRUZZ MEDIA.

CNN Indonesia. (2021). Juli 2021, Bulan dengan Kasus Kematian Covid-19 Terbanyak. Retrieved from https://www.cnnindonesia.com/nasiona 1/20210729175943-20-673976/juli2021-bulan-dengan-kasus-kematiancovid-19-terbanyak

Depkes RI. (2009). Sistem kesehatan nasional, Jakarta.
Elvianasti, M., Roza, L., Maesaroh, M., \& Yarza, H. N. (2021). Edukasi COVID19 Bagi Warga Lansia di RW 05 Kelurahan Jaticempaka Pondok Gede. Selaparang: Jurnal Pengabdian Masyarakat Berkemajuan, 4(2), 417420.

Family Caregiver Alliance. (2006). Caregivers count too! A toolkit to help practitioners assess the needs of family caregivers, 1-98. Retrieved from http://scholar.google.com/scholar?hl=e $\mathrm{n} \& \mathrm{btnG}=$ Search\&q$=$ intitle:Caregivers+ Count+Too!+A+Toolkit+to+Help+Pra ctitioners+Assess+the+Needs+of+Fami $1 \mathrm{y}+$ Caregivers $\# 0$

Hwang, B., Luttik, M. L., Dracup, K., \& Jaarsma, T. (2010). Family Caregiving for Patients With Heart Failure: Types of Care Provided and Gender Differences. Journal of Cardiac Failure, 16(5), 398-403. https://doi.org/10.1016/j.cardfail.2009. 12.019

Janssen, D. J. A., Spruit, M. A., Wouters, E. F. M., \& Schols, J. M. G. A. (2012). Family Caregiving in Advanced Chronic Organ Failure. Journal of the American Medical Directors Association, 13(4), 394-399. https://doi.org/10.1016/j.jamda.2011.04 .017

Kementerian Dalam Negeri. (2020). Pedoman Umum Menghadapi Pandemi COVID-19 Bagi Pemerintah Daerah: Pencegahan, Pengendalian, Diagnosis dan Manajemen. Retrieved November 5, 2020, from https://covid19.go.id/p/panduan/kemen dagripedoman-umum-menghadapipandemi-covid-19-bagi-pemerintahdaerah

Kementerian Kesehatan RI. (2020a). 5 M Di Masa Pandemi COVID-19 Di Indonesia. Retrieved from http://www.padk.kemkes.go.id/article/r 
ead/2021/02/01/46/5-m-dimasapandemi-covid-19-di-indonesia.html

Kementerian Kesehatan RI. (2020b). Orang Dengan Penyakit Tidak Menular Berisiko Tinggi Terinfeksi COVID-19. Retrieved from https://www.kemkes.go.id/article/view/ 20070500003/orang-dengan-penyakittidak-menular-berisiko-tinggiterinfeksi-covid-19.html

Kementerian Kesehatan RI. (2020c). Pedoman Umum Menghadapi Pandemi COVID-19 bagi Pemerintah daerah. Retrieved from https://covid19.kemkes.go.id/download s/?dl_cat=7\#.XwQvm20zbIV

Melia, S., Triana, H., \& Prasetyo, Y. A. (2021). Edukasi Kesehatan Lansia dan Adaptasi Kebiasaan Baru Melalui Media Live Streaming Youtube. In In Prosiding Seminar Nasional LPPM $U M P$ (pp. 150-153).

National Alliance for Caregiving. (2015). Caregiving in the U.S.- AARP 2015 Report. Bethesda, Md: National Alliance for Caregiving; 2015. Retrieved from https://www.aarp.org/content/dam/aarp /ppi/2015/caregiving-in-the-unitedstates-2015-report-revised.pdf.

National Alliance for Caregiving, \& AARP. (2004). Caregiving in the U.S., (April), 1-83.

Rahayu, S. (2017). 印尼心藏衰竭病人之家 屬照顧者的衛教需求. 成功大學護理 學系學位論文, 1-77. Retrieved from http://www.airitilibrary.com/Publicatio n/alDetailedMesh?docid=U00260802201717114900

Rahayu, S. (2019). Penyuluhan kesehatan: pentingnya melibatkan keluarga dalam perawatan hipertensi. Jurnal Abdimas Kesehatan (JAK), 1(3), 170-174.

Rahayu, S., \& Rahmawati, T. (2019).
Karakteristik dan kesediaan caregivers keluarga dari pasien kronis tentang pembentukan support group. Jurnal Ilmiah Keperawatan Altruistik, 2(2), 53-63.

Rahayu, S., \& Rahmawati, T. (2020). Online support group untuk caregivers keluarga. Jurnal Ilmu Keperawatan Dan Kebidanan, 11(1), 126-133.

Yusriani, Mora, Wati, N. M. N., Nuryanti, T., Budi, A., Wahyuni, D., ... Qasim, M. (2020). Masa-masa COVID-19: Mengenal dan Penanganan Dari Berbagai Perspektif Kesehatan. Banten: CV A.A Rizky.

Zhou, W. (2020). The Coronavirus Prevention Handbook. Cina: Hubei Science and Technology Press. 